\title{
Retinal nerve fiber layer atrophy as relevant feature for diffuse unilateral subacute neuroretinitis (DUSN): case series
}

\author{
Atrofia das camadas de fibras nervosas da retina como característica \\ relevante na neurorretinite subaguda difusa unilateral (DUSN): \\ série de casos
}

\author{
Antonio Marcelo Barbante Casella ${ }^{1}$ \\ Michel Eid Farah² \\ Eduardo Cunha de Souza ${ }^{3}$ \\ Rubens Belfort Jr. ${ }^{4}$ \\ Ana Paula Miyagusko Taba Ogiuido ${ }^{5}$
}

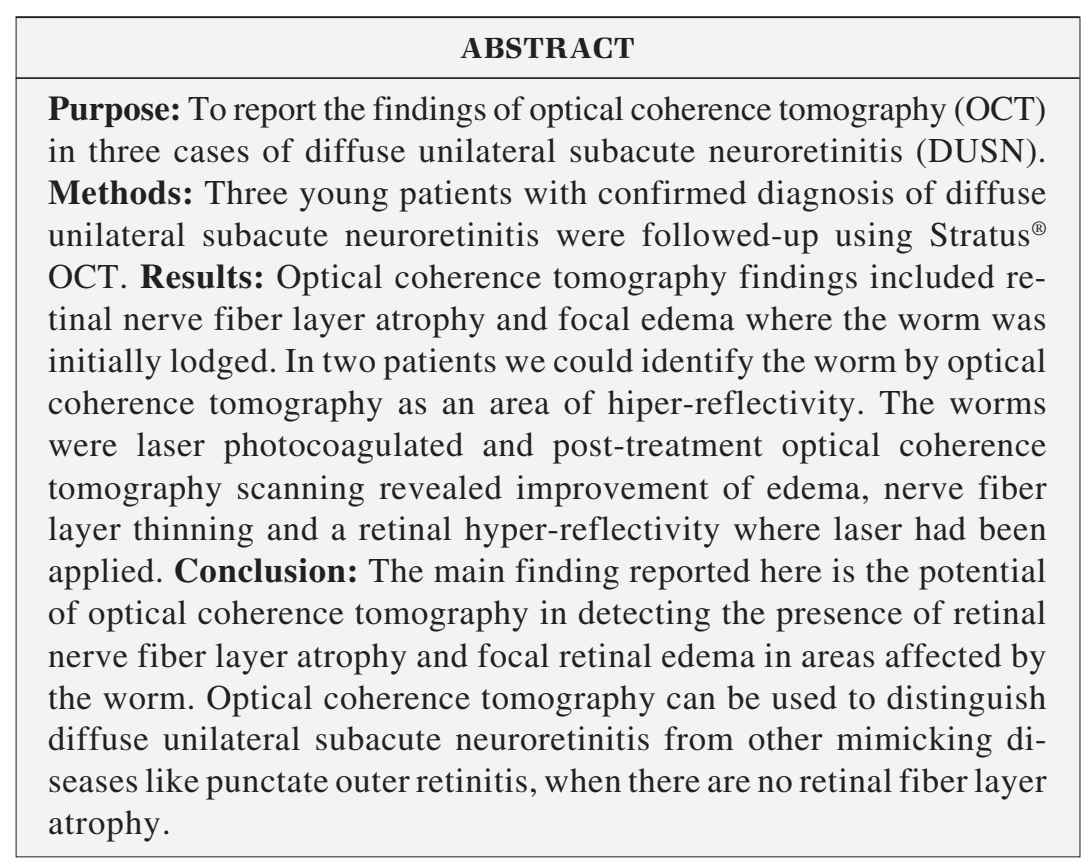

Keywords: Retinitis/diagnosis; Optic neuritis; Eye infections, parasitic; Laser therapy; Optic nerve/parasitology; Optic atrophy; Retina; Tomography, optical coherence; Case reports

\section{INTRODUCTION}

Diffuse unilateral subacute neuroretinitis (DUSN) is caused by a subretinal nematode producing multifocal choroiditis and optic nerve inflammation in the early stage and optic nerve atrophy, retinal vessel narrowing and diffuse changes in the retinal pigmented epithelium (RPE) in the late stage of the disease ${ }^{(1)}$.

The differential diagnosis of early-stage DUSN is based on the presence of multifocal choroiditis, such as multiple evanescent white dot syndrome and toxoplasmosis, especially in the form of punctate outer retinitis ${ }^{(2)}$.

The optical coherence tomography (OCT) is a diagnostic tool that allows the measurement of retinal nerve fiber layer thickness with no risks. OCT may be of additional help in cases where the worm was not detected.

The following cases presented in this report are about patients diagnosed with DUSN that received additional examination with OCT (Stratus- 
OCT; Carl Zeiss Meditec) to detect the retinal nerve fiber layer atrophy. The OCT scans were performed by an experienced physician for accurate measurements using the automatic software measurements tool.

\section{Case 1}

A 16 year-old male patient presented with a 3-year history of decreased vision on the left eye. Upon examination, the affect eye had optic nerve atrophy, diffuse changes in the RPE and white-yellowish lesions in the posterior pole. In addition, a small nematode measuring approximately $700 \mu \mathrm{m}$ was found in the papillomacular bundle (Figure 1A). The patient was submitted to scanning with Stratus OCT-3 (Figure 1B). On the day the scan was performed the worm had moved temporally towards the fovea. The nematode was visualized in the subretinal space as a homogenous area of hyper-reflectivity and the retinal nerve fiber layer showed signs of atrophy (Figure 1C). OCT revealed focal edema in the area previously occupied by the worm.

After laser photocoagulation the patient's visual acuity increased to 20/400 from 20/800. Subsequent OCT imaging revealed retinal thinning and hyper-reflectivity that extended into the choroid corresponding to the chorioretinal scar observed clinically and partial resolution of edema.

\section{Case 2}

A 11 year-old female presented with a 3-month history of decreased visual acuity to finger counting at 0.50 meters. The examination revealed white areas on the retina and a nematode in the subretinal macular space with distinct features (Figure 1D). The patient was submitted to scanning with Stratus OCT-3. Neuroretina showed signs of atrophy and a nematode perpendicular to all layers of the retina (Figure 1E). The worm was photocoagulated. After treatment, visual acuity was the same and the optic nerve was pale. Six months after treatment OCT images showed retinal nerve fiber layer atrophy and hyper-reflectivity that extended into the choroid corresponding to the chorioretinal scar clinically observed.

\section{Case 3}

A 13 year-old male presented with a 7-month history of decreased visual acuity. The examination revealed white areas

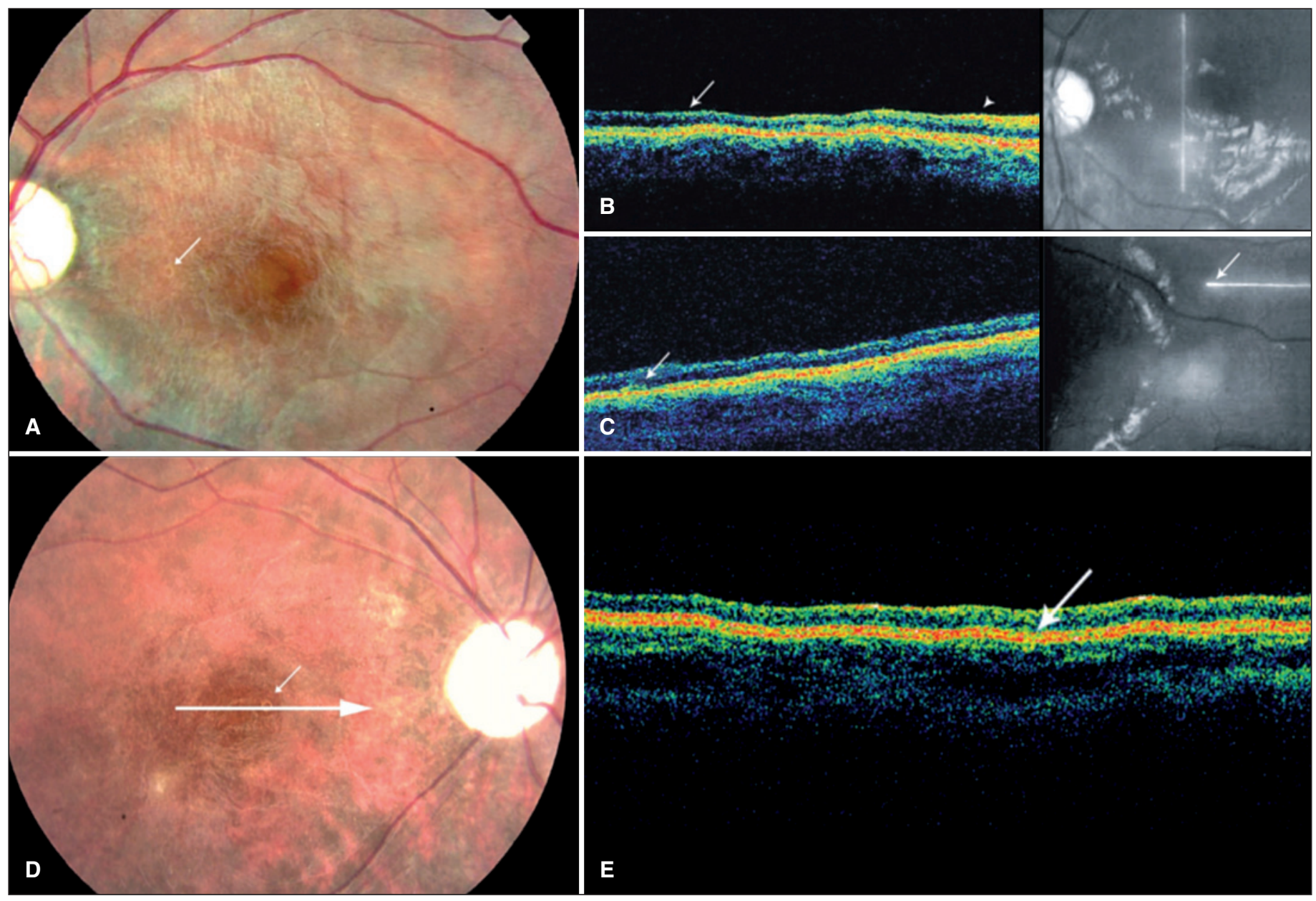

Figure 1 - Color retinography of Case 1, the arrow indicates the nematode in situ (A). OCT of the area where the nematode was lodged showing retinal nerve fiber atrophy (arrow) and edema (arrow head) (B-C). Color retinography of Case 2 (D), the arrow indicates the nematode in situ. OCT showing signs of neuroretina atrophy and nematode transponding outer and some inner layers of the retina $(E)$. 
on the retina and a nematode in the subretinal space (Figure 2A), which was subsequently photocoagulated (Figure 2B). Although visual acuity improved to 20/40 from 20/400, the optic nerve remained somewhat pale. Post-treatment OCT images of this patient showed considerable retinal nerve fiber layer atrophy (Figure 2C), and the fundus pictures showed no activity as white dots lesions.

\section{DISCUSSION}

DUSN usually causes blindness in children, especially in tropical regions ${ }^{(3)}$. The differential diagnosis may be difficult to establish, especially when the worm is not found, which is very often because of its microscopic size and high mobility. The visual prognosis, though, is much better when the etiologic agent is early detected and treated ${ }^{(4-6)}$.

OCT may be helpful when DUSN is suspected, by providing detailed information of the retinal nerve fiber layer and areas of edema and has not been associated with side effects, although it is rarely possible to find the actual worm. When the worm is found it is often seen as near grayish-white lesions possibly indicating the parasite's trail (personal experience).

In this study we examined patients diagnosed with DUSN that received additional examination with OCT and detected in all of them retinal nerve fiber layer atrophy, differently than other DUSN mimicking disorders.

By OCT, we have shown here that in DUSN cases diffuse retinal nerve fiber layer atrophy (Figure 1C, 1E, 2C) and focal edema in areas affected by the worm are present (Figure 1B, $1 \mathrm{E})$ as well as two indicative images of the worm presence (Figure 1C, 1E).

Some authors observed by OCT, that retinal nerve fiber layer thickness in DUSN patients is directly proportional to visual acuity ${ }^{(7)}$. Conversely, in Case 3 , it was observed that a profund lesion of the retinal nerve fiber layer is not accompanied by severe visual acuity loss.

We observed that the presence of retinal nerve fiber layer atrophy is a relevant feature in DUSN cases, even in patients with good visual acuity. At this initial level of injury, the visual acuity still can be improved, like reported in case three. Therefore, OCT imaging to monitor nerve fiber loss is recommended as an adjunct tool to support diagnostic and of some prognostic value in DUSN.

Many questions remain to be answered or deserve further investigation, such as whether the level of nerve fiber layer damage and acuity recovery can be correlated in early-stage DUSN, to how the nerve fibers respond to treatment, to how steroids affect the morphology of the damage after laser application, and Fourier-domain (ultrahigh resolution spectral) optical coherence tomography study may reveal further details and offer a better worm delineation.

\section{RESUMO}

Objetivo: Demonstrar os achados da tomografia de coerência óptica em três casos de neurorretinite subaguda difusa unilateral (DUSN). Métodos: Os pacientes com diagnóstico confir-

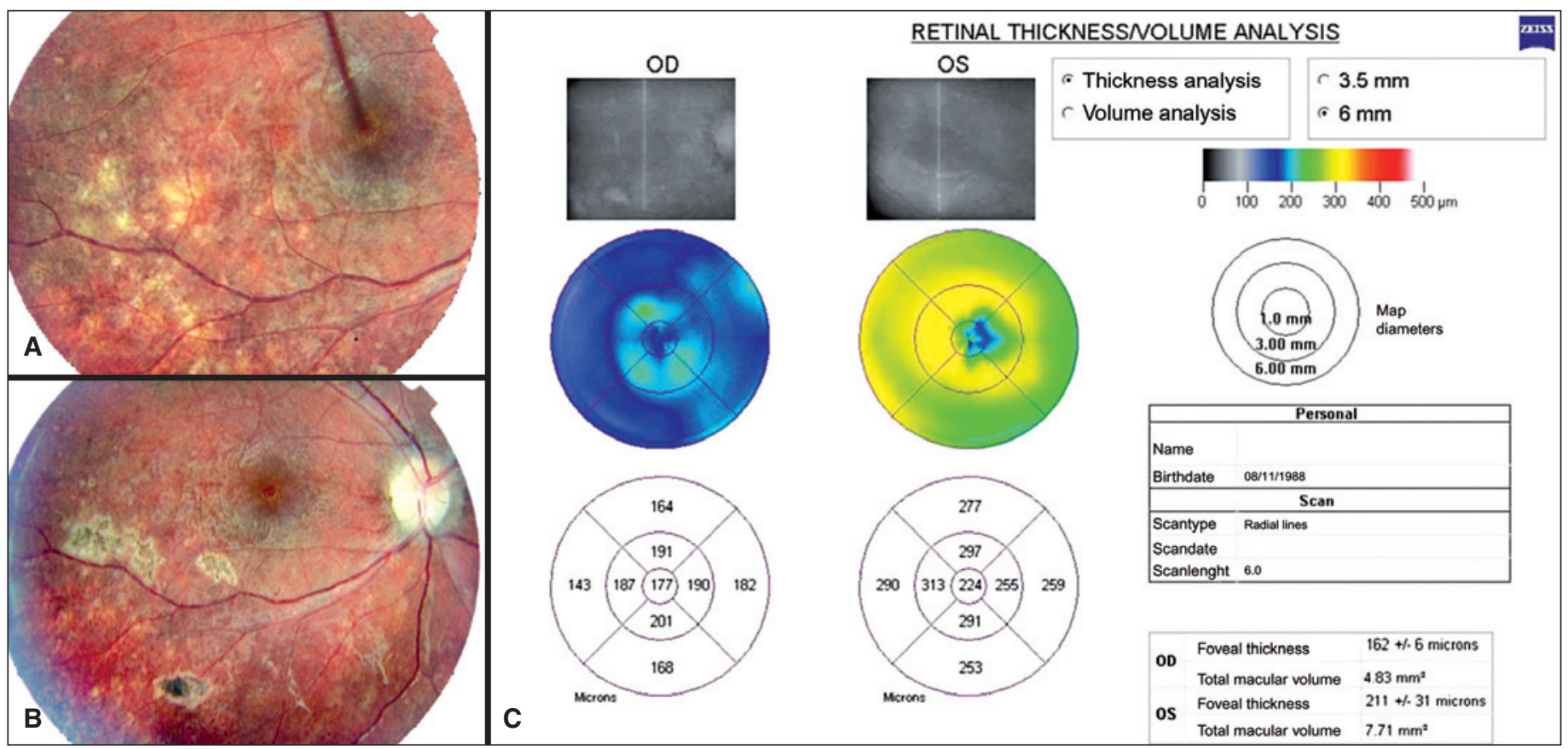

Figure 2 - Retinography of Case 3, showing areas of retinal edema (A). After laser treatment the inflammatory lesions disappeared and the optic nerve shows signs of atrophy (B). OCT showing significant nerve fiber layer thinning in spite of improvement in visual acuity (C). 
mado de neurorretinite subaguda difusa unilateral realizaram seguimento pré e pós-tratamento por meio da tomografia de coerência óptica, Stratus ${ }^{\circledR}$ OCT. Resultados: Os achados marcantes da tomografia de coerência óptica foram a atrofia das camadas de fibras nervosas da retina e edema da retina localizado em áreas nas quais a larva esteve. Em dois pacientes pôde-se localizar a larva no espaço sub-retiniano por meio da tomografia de coerência óptica, que se traduziu por pequena área densa (hiperrefletividade). As larvas foram fotocoaguladas a laser e os achados da tomografia de coerência óptica após o tratamento demonstrou melhora do edema, afinamento das camadas de fibras nervosas e hiperrefletividade no local da aplicação do laser. Conclusão: Os principais achados na tomografia de coerência óptica foram a atrofia difusa das camadas de fibras nervosas e o edema localizado nas áreas afetadas pela larva. A tomografia de coerência óptica pode ser usado para diferenciar neurorretinite subaguda difusa unilateral de doenças que a simulam, como retinite punteada externa, que não manifesta alterações das camadas de fibras nervosas.
Descritores: Retinite/diagnóstico; Neurite óptica; Nervo óptico/parasitologia; Infecções oculares parasitárias; Terapia a laser; Atrofia óptica; Retina; Tomografia de coerência óptica; Relatos de casos

\section{REFERENCES}

1. Gass JD, Braunstein RA. Further observations concerning the diffuse unilateral subacute neuroretinitis syndrome. Arch Ophthalmol. 1983;101(11):1689-97.

2. Doft BH, Gass DM. Puntacte outer retinal toxoplasmosis. Arch Ophthalmol. 1985;103(9):1332-6.

3. Souza EC, Cunha SL, Gass JD. Diffuse unilateral subacute neuroretinitis in South America. Arch Ophthalmol. 1992;110(9):1261-3.

4. Casella AM, Farah ME, Belfort R Jr. Antihelminthic drugs in diffuse unilateral subacute neuroretinitis. Am J Ophthalmol. 1998;125(1):109-11.

5. Souza EC, Abujamra S, Nakashima Y, Gass JD. Diffuse bilateral subacute neuroretinitis: first patient with documented nematodes in both eyes. Arch Ophthalmol. 1999;117(1):1349-51.

6. Myint K, Sahay R, Mon S, Saravan VR, Narendran V, Dhilon B. "Worm in the eye": the rationale for treatment of DUSN in south India. Br J Ophthalmol. 2006;90(9):1125-7.

7. Gomes AH, Garcia CA, Segundo P de S, Garcia Filho CA, Garcia AC. Optic coherence tomography in a patient with diffuse unilateral subacute neuroretinitis. Arq Bras Oftalmol. 2009;72(2):185-8. 